\title{
Development of Multimultural PKN Interactive Learning Multimedia Development in Class IV SD IT NU Tanjung Morawa Academic Year 2018/2019
}

\author{
Surahmawati Dwi Ririn ${ }^{1}$, Reh Bungana Br Perangin-angin ${ }^{2}$, R. Mursid ${ }^{3}$ \\ 1,2,3 Postgraduate Basic Education, Medan State University, Indonesia \\ dwiririn0695@gmail.com
}

\begin{abstract}
The purpose of this study was to determine the feasibility of multicultural-based interactive learning multimedia used in thematic learning at SD IT NU Tanjung Morawa and determine the effectiveness of the use of multicultural-based interactive learning multimedia used in thematic learning at SD IT NU Tanjung Morawa. The subjects of this study were the fourth grade students at SD IT NU Tanjung Morawa in 20118/2019, amounting to 30 people. As the object of this research is learning media, the scale of students' responses to learning media and student learning outcomes tests. The development model that will be used to develop learning media tools in this study is the Thiagarajan model known as the Four-D (Model 4-D). The 4-D model was chosen because it is systematic and appropriate for developing learning tools. The results of the study are multicultural-based interactive learning media that is used in the fourth grade thematic learning at SD IT NU Tanjung Morawa. multicultural-based interactive learning media used in class IV thematic learning at SD IT NU Tanjung Morawa effectively used.
\end{abstract}

Keywords

PPKn; multicultural; interactive multimedia

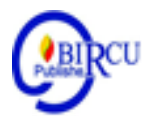

\section{Introduction}

Education in Indonesia is a process of developing a society and government that is carried out consciously and responsibly for the survival and life of the next generation. Education is also an integral part of community life in the global era which must provide and facilitate the growth and development of intellectual, social and personal skills.

The learning process occurs because of the interaction of a person with his environment. The relation is that learning requires interaction, it is intended that the learning process is a communication process, meaning that there is a process of delivering a message from someone (the source of the message) to someone or a group of people (the recipient of the message). The learning process is influenced by the environment, including students, teachers, modules, magazines, interactive learning media and various other learning resources. In addition, educational innovation is also a primary activity in the context of application of learning technology especially ICT based. So that it is expected to be able to improve the quality of education which has an impact on better learning outcomes and innovation in the world of education also lies in the power of thinking that produces ideas as a design technology that must be had in the field of education and learning. Accordingly, in order to provide a new nuance in learning we must develop ICTbased innovative learning, which is interactive multimedia. For this reason, in this interactive multimedia learning process, meaningful education strongly supports the realization of quality educational goals. Students also need guidance, encouragement, and adequate opportunities to learn and learn things that are needed in their lives. 
Citizenship education is a subject that can form a complete Indonesian human being based on Pancasila, laws and norms that are appropriate and applicable in Indonesia. Pancasila and Citizenship Education subjects need to be delivered to all students ranging from elementary school to high school to equip students with social skills so that students have moral, character in the midst of society (Panggabean, 2019). According to Susanto (2014: 225) said that citizenship education is a subject that is used as a vehicle to develop and preserve noble and moral values that are rooted in the culture of the Indonesian nation. This noble and moral value is expected to be able to realize the forms of daily life behavior of students both as individuals and members of the community and be able to equip students with a basic knowledge and abilities regarding relations between citizens and the state. Citizens have the fundamental goal to move the life of democracy following the state of the social-political environment. The involvement of citizens as the subject of democracy will give birth to a strong citizen character (Mukmin, 2019).

Education is the main capital for humans to prosper. The importance of the role of education in improving welfare requires the need for equal distribution of education in each region regardless of socioeconomic, gender and racial backgrounds (Harahap, 2020). Along with the development of the age of science and technology, it is directly that the mindset of society will develop in everything. This is a major influence, especially for the world of education which emphasizes the existence of new innovations that can cause a qualitative change that is different from before. A responsibility in carrying out the evaluation lies in the administration of education in schools, where the teacher plays an active role as well as the responsibility for expanding new ideas, both to students and the community through the teaching process in the classroom.

So based on this, it was concluded that the main factors causing errors in teaching so far one of them is the use of instructional media which is still very minimal using only cardboard media and makeshift images. In addition, teachers always rely on the use of textbooks alone without any supporting media so that the impact of students is only memorization.

The problems above, are inseparable from the share of a learning medium used. Learning media in the form of animation can support the understanding and activeness of students in learning and make the easiest strategies to be able to cause feedback between students and teachers so that the teaching and learning process will be more effective, creative, and interactive.

The observation results at SD IT NU Tanjung Morawa Deli Serdang Regency, in the implementation of the teaching and learning process some teachers in implementing the 2013 curriculum, especially the Civics lesson, were still experiencing many obstacles, so the learning process was still dominated by teachers as learning resources and the lack of tools and media which supports the learning needs of students because they tend to use only books. Then the problem obtained by the researcher is the low student learning outcomes that can be seen from the results of the even semester semester 2018/2019 school year. PPKn grade IV-A exam results from 30 students only 13 students who have grades $>70$ and 17 students who have grades $<70$, meaning only 13 students have reached the completeness standard and 17 students who have not reached the completeness standard. Whereas the results of the PPKn class IV-B examination from 30 students only 10 students who had grades> 70 and 20 students who had grades $<70$, meant that only 10 students had reached the completeness standard and 20 students who had not reached the completeness standard. Broadly speaking, researchers see that student learning outcomes in learning PPKn are still very low.

Overcoming the above problems, it is necessary to develop multimedia learning that supports the learning of PPKn students according to criteria. Development of interactive learning multimedia Macromedia Flash 8 is a medium used by teachers to create student 
attraction in the learning process takes place and is actively involved in the learning process that is not boring and this media fits perfectly with the goals expected to be achieved. In this interactive multimedia learning media has a variety of applications and packaging a variety of media ranging from pictures, sounds, videos to display various types of animations and simulations, and interactive multimedia is packaged more concisely and has a high interactive side.Interactive multimedia is designed as well as possible in order to be able to attract the attention of students, so students feel themselves not bored, but students do activities while playing that is fun and motivates students to learn.

The objectives of this research are: 1) to find out the level of feasibility of developing multicultural PPKn interactive learning multimedia in class IV of SD IT NU Tanjung Morawa in Academic Year 2018/2019, 2) To determine the effectiveness of developing multicultural PPKn interactive learning multimedia in class IV Tanjung Morawa NU Elementary School, School Year 2018/2019.

\section{Review of Literature}

\subsection{Understanding Learning Media}

Gerlach \& Ely quoted from Arsyad (2017: 3) say that the media when understood in broad outline are humans, material, or events that build conditions that make students able to obtain knowledge, skills, or attitudes. In this sense, teachers, textbooks, and the school environment are media. More specifically, the notion of media in the teaching and learning process tends to be interpreted as graphic, photographic, or electronic tools for capturing, processing, and rearranging visual or verbal information.

According Arsyad (2017: 4) learning media can be interpreted as a medium that carries a message in the form of information that is instructional and contains teaching intentions. Learning media include tools that are used physically to deliver teaching material. The National Education Association defines media as a form of print and audio-visual communication that can be manipulated, seen, heard or read.

\subsection{Benefits and Functions of Learning Media}

Teaching media can enhance the learning process of students in teaching which in turn is expected to improve the learning outcomes they achieve. Utilization in using media is seen and adjusted to the characteristics and needs of students, not only must they use sophisticated and up to date media, but emphasizes the function and suitability of needs in teaching. The main function of teaching media is as a teaching aid in teaching as a support for the use of teaching methods used by teachers.

\subsection{Selection of Learning Media}

That if the teacher wants to choose learning media as a tool in the learning process, the following factors must be considered, namely the objective factor, the effectiveness and efficiency factor, the situation and condition, and the teacher and student ability factor.

\subsection{Types of Learning Media}

There are many types of learning media and kinds. Starting from the simplest and cheapest to sophisticated and expensive media. There are media that can be made by themselves, there are media produced from the factory. In essence the media is one component of the learning system. As a component of the learning system, the media should be part and must be in accordance with the overall learning process. The media chosen for learning activities should be adjusted to the needs of students and the objectives to be achieved. 
Rusman, et al (2012) said that there are five types of media that can be used in the learning process: Visual Media, Audio Media, Audio-Visual Media, Presenter Media Groups and Object-Based Media and Computer-Based Interactive Media. Based on the five types of media, object-based media and computer-based interactive media are very suitable and media that can be used as a source of communication media between teachers and students. The most important thing is this media group that students not only pay attention to the media or objects, but are also required to interact while attending the lesson.

\subsection{The Nature of Interactive Multimedia}

Interactive multimedia is something that is used to convey learning material by using computers to create and combine text, graphics, audio and moving images (video and animation) equipped with controllers that can be operated.

\subsection{Advantages of Interactive Multimedia}

Multimedia has advantages if it is used as a learning medium because it makes learning more interactive, there is feedback between teachers and students (responses), and motivates students to be more active in learning.

\subsection{Weaknesses Interactive Multimedia}

Multimedia also has weaknesses to be used as learning media because it requires expensive costs and requires careful and professional planning in their fields.

\subsection{Characteristics of Interactive Learning Multimedia}

According to Daryanto (2010: 53) said that the characteristics of multimedia learning are as follows: (1) Having more than one convergent media, for example combining elements of audio with visual; (2) Be interactive, in the sense of having the ability to accommodate user responses; (3) Be independent, namely providing convenience and completeness of content in such a way that users can use without guidance from others.

\subsection{Benefits of Interactive Learning Multimedia}

Utilization of multimedia technology as an interactive learning method, is one of the learning tools for students, has some basic strengths, as stated by Philips (1997) in Hasrul (2010), namely (1) Mixed. Media using multimedia technology, various existing conventional media can be integrated into one type of interactive media, such as text (blackboard), audio, and video media, which if separated will require more media; (2) User Control. Interactive multimedia implementation technology (IMMI), allows users to browse teaching materials, in accordance with their abilities and background knowledge, while making users more comfortable in learning media content, repeatedly; (3) Simulation and Visualization. Is a special function possessed by interactive multimedia, so that with animation technology, simulation and computer visualization, users will get more real information from information that is abstract. In some curricula required complex understanding, abstract, dynamic and microscopic processes, so that with simulation and visualization of students will be able to develop mental models in cognitive aspects; (4) Different learning styles. Interactive multimedia has the potential to accommodate users with different learning styles.

\subsection{Interactive Learning Multimedia Models}

There are various kinds of interactive multimedia models. The following are interactive learning multimedia models, Model Tutorials, Drill Models, Simulation Models, Model Games. 


\subsection{Multicultural Education}

Multicultural understanding broadly includes experiences that shape general perceptions of age, gender, religion, socioeconomic status, types of cultural identity, language, taste, and special needs. Multicultural education can be understood as an educational process or strategy that involves more than one culture, which is demonstrated through nationality, language, ethnicity, or racial criteria.

As a new discourse, the understanding of multicultural education is actually not yet clear and there are still many education experts who debate it. However, that does not mean that the definition of multicultural education is not apparent. In fact, it is the same as the definition of education which is full of interpretation between one other expert in describing the meaning of education itself. Based on the above understanding, it can be concluded that multicultural based education is an educational strategy that involves cultural diversity in responding to the demographic and cultural changes in the particular community's environment and even the whole world.

\subsection{Multicultural Based Interactive Multimedia}

Interactive multimedia based on multiculturalism is a strategy used to convey learning materials by using computers to create and combine text, graphics, audio and moving images (video and animation) that involve the diversity of cultures and cultures of certain community environments.

\subsection{PPKn as Multicultural Education}

The learning process that uses a multicultural approach emphasizes how to treat students with different socio-cultural backgrounds and interests. In the learning process students are trained to think critically and democratically so that they can find concepts, principles and values for diversity. PPKn learning includes multicultural material and teaches the value of respect and tolerance. PPKn has an important role to prepare students to be able to overcome the difficulties and problems they find in multicultural societies, as well as respecting social differences, culture, and cultural diversity.

Multicultural-based PPKn as a vehicle to foster the diversity of Indonesian society becomes very important to be implemented and integrated into Indonesian education so that every Indonesian citizen can interpret diversity while respecting differences, both individual differences (physical, sex, age, skin color, and height) ), as well as cultural, social, religious, linguistic, ethnic and group differences. Therefore the treatment given must also consider the cultural background. PPKn may not generalize or generalize different people. For this reason, the PPKn plays a very important role in fostering the diversity of Indonesian society so that diversity does not become a source of conflict but rather as a basis for tolerance and respect for the diversity that exists in order to realize a different Indonesian state but remains one.

Based on the discussion above, it can be concluded that multicultural-based PPKn is a learning that teaches that Indonesian citizens have multicultural principles in the life of the nation which are expected to respect and tolerate others.

\subsection{The Nature of Macromedia Flash}

According to Anggra (2008: 2), Macromedia Flash 8 is a software version of Macromedia.inc in the form of graphics and animation programs whose existence is intended for lovers of design and animation to be creative in creating interactive web animations, cartoon animated films, making company profile business presentations or interesting activities and flash games. Flash is an animation program that is very reliable, the reliability of Flash compared to other programs is in terms of the size of the resulting file smaller. 
Therefore, animations produced by flash programs are widely used to make Interactive CDs and other media so that the appearance becomes more interactive (Deni, 2012: 232). The advantages of Macromedia Flash 8 support the technical creation of multimedia software with adequate features and are easy to use to create animations and can produce files in the form of. Swf and exe according to development needs, then deemed sufficient to be used as a tool to create interactive media according to the purpose author.

\section{Research Methods}

This type of research used is Research and Development or Research and Development (R\&D). Subjects in this study were media experts, material experts, teachers and class IV-A students as many as 36 people as the experimental class and class IV-B as many as 35 people as the control class at SD IT NU Tanjung Morawa Deli Serdang Regency consisting of 1 lecturer media expert, 1 material lecturer, 1 design expert, 1 class teacher and 32 students. Meanwhile the object of this research is the development of interactive multimedia learning media on multicultural citizenship education subjects.

The selection of research subjects is based on the lack of instructional media in the form of interactive learning multimedia in Civics Education subjects. This research was conducted in class IV of SD IT NU Tanjung Morawa in Deli Serdang Regency. This research is planned to be conducted in the even semester of the 2018/2019 school year for 2 months, November and January. The data collection techniques used in the development of learning media based on interactive multimedia data, questionnaires or questionnaires.

\section{Discussion}

\subsection{Pretest}

From the data obtained above, it can be summarized as the table below:

Table 1. Recapitulation of Student Learning Outcomes during the pretest

\begin{tabular}{|c|c|c|c|c|c|c|c|}
\hline \multirow{2}{*}{ Num } & \multirow{2}{*}{ Range } & \multirow{2}{*}{ Alphabet } & \multicolumn{4}{|c|}{ Frequency } & \multirow{2}{*}{ Information } \\
\hline & & & IV-A & $\%$ & IV-B & $\%$ & \\
\hline 1 & $2,85-3,17$ & B & 7 & $23.3 \%$ & 6 & $20.0 \%$ & Complete \\
\hline 2 & $2,51-2,84$ & B- & 5 & $16.7 \%$ & 11 & $36.7 \%$ & Incomplete \\
\hline 3 & $2,18-2,50$ & $\mathrm{C}+$ & 3 & $10.0 \%$ & 3 & $10.0 \%$ & Incomplete \\
\hline 4 & $1,85-2,17$ & $\mathrm{C}$ & 2 & $6.7 \%$ & 1 & $3.3 \%$ & Incomplete \\
\hline 5 & $1,51-1,84$ & $\mathrm{C}-$ & 13 & $43.3 \%$ & 9 & $30.0 \%$ & Incomplete \\
\hline \multicolumn{3}{|c|}{ Total } & 30 & $100 \%$ & 30 & $100 \%$ & \\
\hline
\end{tabular}
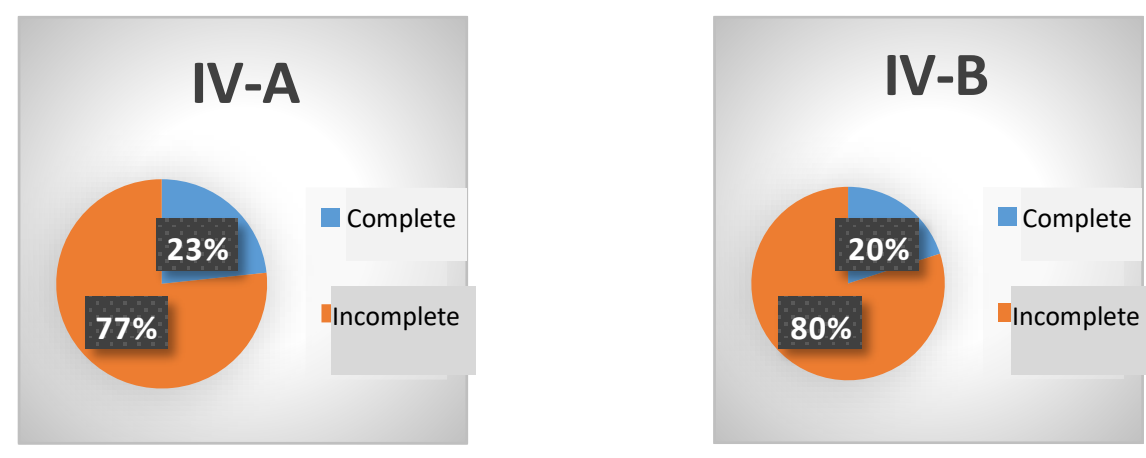

Figure 1. Diagram of the pretest results of class $A$ and class $B$ 


\subsection{Post Test 1}

From the data obtained, it can be summarized as the table below:

Table 2. Recapitulation of Student Learning Outcomes during the post test 1

\begin{tabular}{|c|c|c|c|c|c|c|c|}
\hline \multirow{2}{*}{ Num } & \multirow{2}{*}{ Range } & \multirow{2}{*}{ Alphabet } & \multicolumn{4}{|c|}{ Frequency } & \multirow{2}{*}{ Information } \\
\hline & & & IV-A & $\%$ & IV-B & $\%$ & \\
\hline 1 & $3,85-4,00$ & $\mathrm{~A}$ & - & - & 1 & $3 \%$ & Complete \\
\hline 2 & $3,51-3,84$ & A- & & & & & Complete \\
\hline 3 & $3,18-3,50$ & $\mathrm{~B}+$ & 12 & $40 \%$ & 13 & $43 \%$ & Complete \\
\hline 4 & $2,85-3,17$ & $\mathrm{~B}$ & 4 & $13 \%$ & 8 & $27 \%$ & Complete \\
\hline 5 & $2,51-2,84$ & B- & 12 & $40 \%$ & 7 & $23 \%$ & Incomplete \\
\hline 6 & $2,18-2,50$ & $\mathrm{C}+$ & 2 & $7 \%$ & 1 & $3 \%$ & Incomplete \\
\hline & Total & & $100 \%$ & 1 & 30 & $100 \%$ & \\
\hline
\end{tabular}
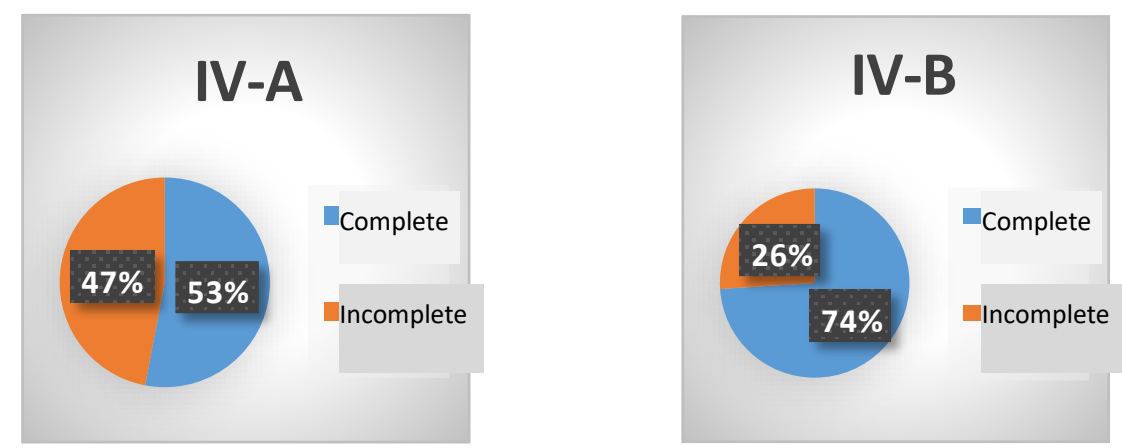

Figure 2. Diagram of the results of class $A$ and class B tests

\subsection{Post Test II}

From the data obtained, it can be summarized as the table below:

Table 3. Recapitulation of Student Learning Outcomes during the posttest II

\begin{tabular}{|c|c|c|c|c|c|c|c|}
\hline \multirow{2}{*}{ Num } & \multirow{2}{*}{ Range } & \multirow{2}{*}{ Alpha } & \multicolumn{4}{|c|}{ Frequency } & \multirow{2}{*}{ Information } \\
\hline & & & IV-A & Percentage & IV-B & Percentage & \\
\hline 2 & $3,51-3,84$ & A- & 9 & $30 \%$ & 13 & $43 \%$ & Complete \\
\hline 3 & $3,18-3,50$ & $\mathrm{~B}+$ & 15 & $50 \%$ & 13 & $43 \%$ & Complete \\
\hline 4 & $2,85-3,17$ & $\mathrm{~B}$ & 5 & $17 \%$ & 3 & $10 \%$ & Complete \\
\hline 5 & $2,51-2,84$ & B- & 1 & $3 \%$ & 1 & $3 \%$ & Incomplete \\
\hline & Total & & 30 & $100 \%$ & 30 & $100 \%$ & \\
\hline
\end{tabular}
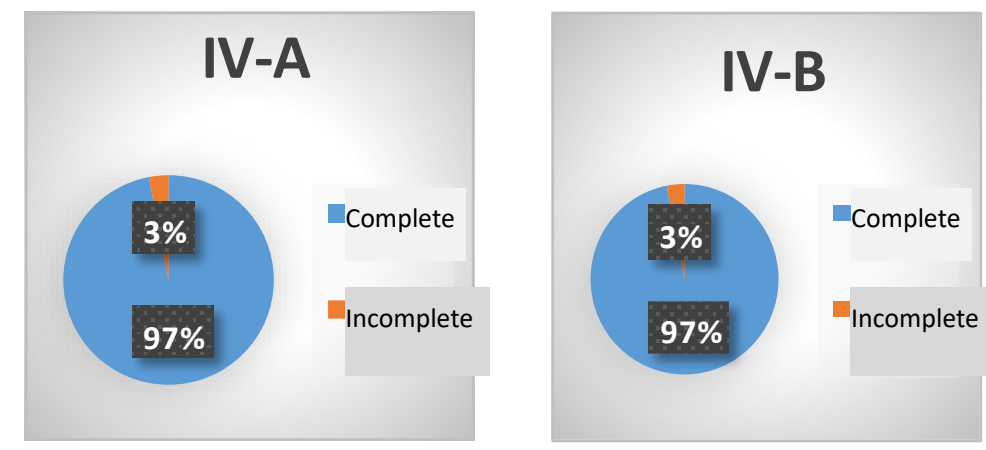

Figure 3. Diagram results of class A and class B posttest II 
So the overall results of the pretest, posttest I, and posttest II can be illustrated by the diagram below.

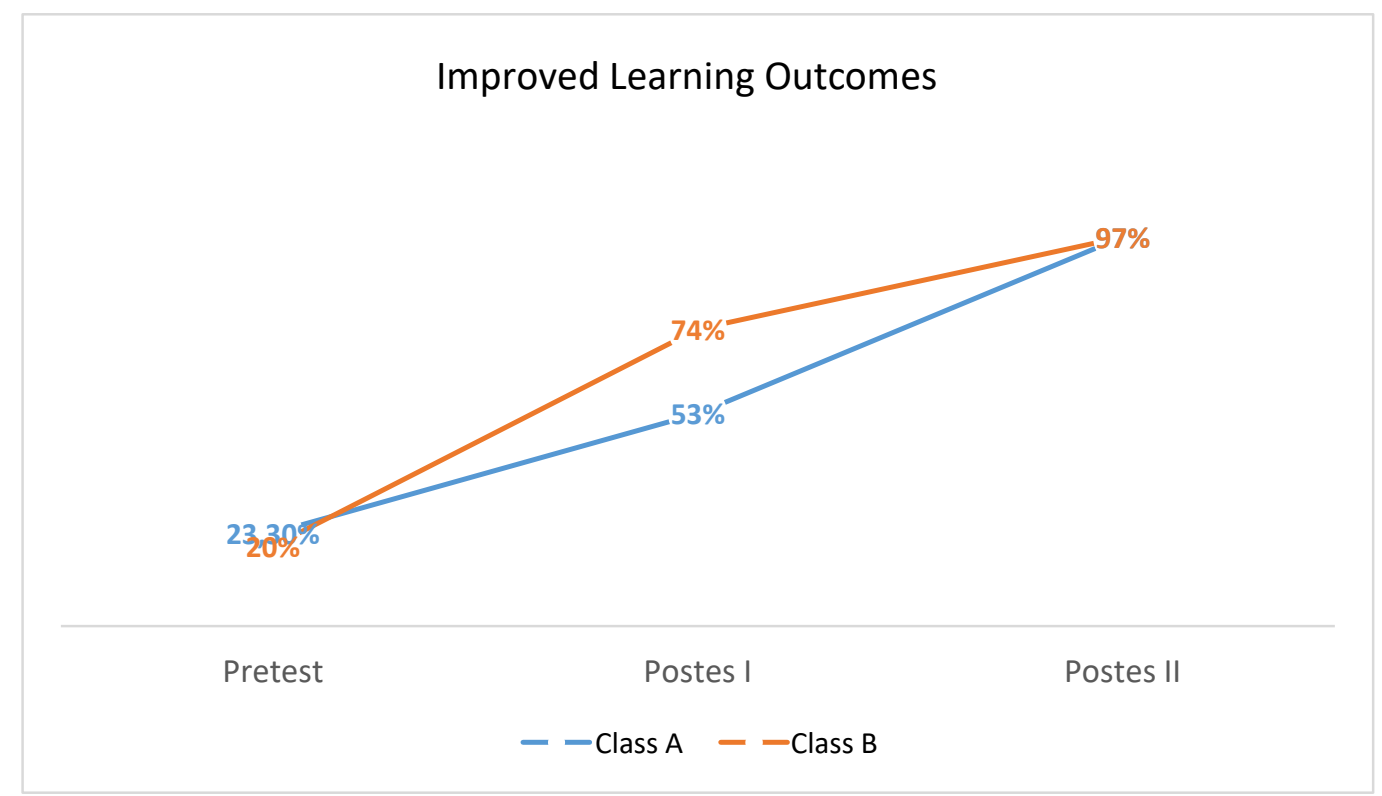

Figure 4. Diagram of Improvement of Pretest, Posttest I and Posttest II Learning Outcomes

\subsection{Analysis of improvement through Gain Score}

The results of calculations using Ms Excel obtained an average Gain value in class IVA of 0.5 , as well as class IV-B of 0 , this gain value is then interpreted into the gain value criteria where both are in the medium category.

With these results it can be concluded that students who use learning media by using macromedia flash can improve learning outcomes on PPKn subjects material on ethnic and cultural diversity in Indonesia

\section{Conclusion}

Based on the description of the research results, it can be concluded as follows:

1. This research and development resulted in a product in the form of multicultural-based interactive learning media using the Macromedia Flash 8 application with the material diversity of my nation's culture for learning IVE Class IV elementary school. Stages are carried out to produce interactive learning media using the 4-D model. Can be known the results of the validation of material, media and design experts, can be known an average of 3.7 or very good. The results of the teacher and student response questionnaire as a whole showed a good response to the use of multicultural-based interactive learning media in the learning process.

2. Multicultural-based interactive media proved to be effectively used because learning outcomes in control and experiment classes increased in PPKn subjects on ethnic and cultural diversity. 


\section{References}

Anggra. (2008). Memahami Teknik Dasar Pembuatan Game Berbasis Flash. Yogyakarta : Gava Media

Arsyad, A. (2017). Media Pembelajaran. Jakarta: Raja Grafindo Persada.

Daryanto. (2010). Media Pembelajaran: Peranannya Sangat Penting Dalam Mencapai Tujuan Pembelajaran. Yogyakarta: Gava Media.

Daryanto. (2013). Media Pembelajaran. Yogyakarta: Gava Media.

Harahap, E.S., et al. (2020). Determinant Analysis of Education Inequalities in Indonesia. Budapest International Research and Critics Institute-Journal (BIRCI-Journal), 10671082.

Hasrul. (2010). Langkah-Langkah Pengembangan Pembelajaran Multimedia Interaktif. Jurnal MEDTEK. 2 (1). PP. 102-114

Mukmin, B. A., et al. (2019). Citizenship Politics (Reviewing the Meaning of Democracy in Majanggut I Village, Royal District Pakpak Barat Regency). Budapest International Research and Critics Institute-Journal (BIRCI-Journal), 354-362.

Panggabean, R.H.,et al. (2019). Student Learning Result of Citizenship Education in Internet Learning Media with High Interpersonal Communication in High School Al-Azhar Medan. Budapest International Research and Critics in Linguistics and Education (BirLE) Journal, 491-498.

Rusman, dkk. (2012) Pembelajaran Berbasis Teknologi Informasi dan Komunikasi. Jakarta: Rajawali Pers

Rusman. (2012). Belajar dan Pembelajaran Berbasis Komputer; Mengembangkan Profesionalisme Guru Abad 21. Bandung: Alfabeta.

Susanto, A. (2014). Teori Belajar dan Pembelajaran di Sekolah Dasar. Jakarta : Kencana Prenamedia Group 